\title{
TRAF3 wt Allele
}

National Cancer Institute

\section{Source}

National Cancer Institute. TRAF3 wt Allele. NCI Thesaurus. Code C96378.

Human TRAF3 wild-type allele is located in the vicinity of $14 q 32.32$ and is approximately $127 \mathrm{~kb}$ in length. This allele, which encodes TNF receptor-associated factor 3 protein, plays a role in the modulation of both apoptosis and signaling pathways. 